\title{
Basquetebol: O Jogo Livre com Conceitos como proposta pedagógica da iniciação ao treinamento.
}

\begin{abstract}
André Luiz de Almeida Soares (IC), Thiago José Leonardi (PG), Roberto Rodrigues Paes (PQ) Resumo

Tendo em vista uma perspectiva pedagógica que contribua para o desenvolvimento integral dos jogadores de basquetebol, o processo de ensino-vivência-aprendizagem e treinamento deve ser organizado, sistematizado, aplicado e avaliado, de acordo com cada cenário, em cada modalidade, adequando-se aos objetivos propostos aos personagens em questão. O Jogo Livre com Conceitos apresenta-se enquanto proposta de ensino da modalidade, de forma a contribuir para o desenvolvimento dos praticantes da modalidade na tentativa de evitar problemas comuns no ensino do esporte, como a fragmentação de conteúdos e a especialização esportiva precoce. Acreditamos que o jogo livre com conceitos permite uma diversificada forma de ensinar, sem que haja a exclusão por características individuais, ensinando valores e princípios de jogo e de cidadania através do esporte.
\end{abstract}

Palavras Chave: Basquetebol, Pedagogia do Esporte, Jogo Livre com Conceitos

\section{Introdução}

Cabe à pedagogia do esporte organizar, sistematizar, aplicar e avaliar o processo de ensino-vivência-aprendizagem e treinamento (PEVAT) do esporte1. Portanto, as investigações na área devem contribuir de forma clara às pessoas que atuam no esporte para que 0 processo seja fundamentado e possua o menor número de falhas possível, contribuindo assim, para um melhor ensino das modalidades esportivas.

Para que o processo pedagógico seja completo e contribua para a real formação dos praticantes de esporte, devem ser destacados três referenciais: técnico-tático, socioeducativo e histórico-cultural ${ }^{1}$. Sob essa perspectiva, de contributo ao desenvolvimento integral ${ }^{2}$ dos praticantes do basquetebol, de acordo com cada cenário e objetivo em que se aplica a prática esportiva, apresentamos o Jogo Livre com Conceitos (JLC). O JLC pode ser considerado uma forma de jogo sob princípios básicos, que orientarão as ações técnicas e táticas de cada um dos jogadores. O termo "Livre" se aplica aqui como uma não determinação exclusiva de ação, mas sim de apresentarem-se variadas opções em que 0 jogador deve escolher e tomar uma decisão; essa, por sua vez, causará possíveis reações (dentro dos princípios de ação do JLC) de seus colegas, fazendo com que todos joguem de forma harmoniosa, sistêmica e não pré-estabelecida.

Buscamos apresentar as possibilidades pedagógicas que o JLC pode ser aplicado como contributo ao desenvolvimento da iniciação desportiva.
Utilizamo-nos de revisão bibliográfica para fundamentação de Pedagogia do Esporte e sua relação com a proposta do JLC.

O JLC é uma filosofia de trabalho em equipe, em que todos os atletas da equipe devem se dispor nos espaços da quadra, sem ocupar o espaço de um colega. Todas as ações técnicas acontecem a partir de uma tomada de decisão do jogador, seja o jogador com a posse de bola ou não, em relação às ações de colegas e adversários e sua distribuição no campo de jogo.

Como não há uma única possibilidade de tomada de decisão, os jogadores podem se deslocar por todos os espaços, próximos e distantes do alvo, o que demanda ações técnicas diferentes, ampliando suas vivências no jogo. Dessa forma, o coletivo sobressai o individual, e cada um dos jogadores tem oportunidades iguais de participar ativamente do jogo, pois toda ação individual gera reações coletivas.

\section{Conclusões}

Todo processo de ensino do esporte demanda planejamento, e o JLC, pode facilitar na organização, sistematização, aplicação e avaliação do PEVAT, favorecendo o desenvolvimento integral dos alunos, evitando problemas como a especialização precoce, a exclusão dos menos habilidosos e da fragmentação dos conteúdos da modalidade.

\section{Agradecimentos}

\footnotetext{
Machado, G.V... Pedagogia do Esporte: organização, sistematização, aplicação e avaliação de conteúdos esportivos na educação não formal. 2012. 182f. Dissertação (Mestrado em Educação Física) - Faculdade de Educação Física. Universidade Estadual de Campinas, Campinas, 2012.

Leonardi, T.J.. Galatti, L.R., Paes, R.R., Seoane, A.M.. Pedagogia do Esporte: indicativos para o desenvolvimento integral do indivíduo. Revista Mackenzie de Educação Física e Esporte, São Paulo, v.13, n.1, p. 41-58, ago. 2014
} 